\title{
Gastrin-histamine sequence in the regulation of gastric acid secretion
}

\author{
H L Waldum, A K Sandvik, E Brenna, H Petersen
}

The importance of the vagal nerves in the regulation of acid secretion has been known since Pavlov, ${ }^{1}$ and in 1905 Edkins postulated the existence of the antral hormone gastrin. ${ }^{2}$ In 1920 Popielsky described stimulation of gastric acid secretion by histamine. ${ }^{3}$ Thus, the three major acid secretagogues acetylcholine (from the vagal nerves), gastrin, and histamine have been known for a long time. While vagal activity is regulated via afferent vagal nerves as well as by the central nervous system, gastrin release is stimulated by peptones in the gastric juice ${ }^{4}$ and is inhibited by acid. ${ }^{5}$ Gastrin release is also modulated by the vagal activity, ${ }^{6}$ possibly via gastrin releasing peptide. ${ }^{7}$ Somatostatin, which reaches the gastrin producing $G$ cells via the endocrine as well as the paracrine pathways, also inhibits gastrin release. ${ }^{8}$

The regulation of histamine release, on the other hand, was almost completely unknown until recently. In the 60 s, Kahlson et al showed that food, and especially exogenous gastrin, reduced the content of histamine in the oxyntic mucosa while stimulating the key enzyme in histamine synthesis, histidine decarboxylase, thus indicating that histamine release is an important step in the stimulation of acid secretion. ${ }^{9}$ In fact, MacIntosh ${ }^{10}$ and Code ${ }^{11}$ had previously suggested that the other secretagogues stimulated acid secretion by releasing histamine. Later on, Ekblad described the stimulation of histamine release by acetylcholine in amphibian oxyntic mucosa. ${ }^{12}$ In a recent review Black and Shankley analysed the dose response curves for different secretagogues alone or with a histamine 2 blocker, and concluded that cholinergic stimulation releases histamine. ${ }^{13}$ Using isolated vascularly perfused rat stomach, ${ }^{14}$ we were able to show that gastrin evokes an immediate and dose dependent histamine release. ${ }^{15}$ We had previously studied the relation between the concentration of gastrin and histamine, and acid secretion and showed that gastrin does not augment maximal histamine stimulated acid secretion. ${ }^{16}$ By comparing the effect of gastrin on acid secretion and the resulting concentration of histamine in the gastric venous drainage $^{15}$ with the acid secretory response to histamine infusion, ${ }^{16}$ it is evident that the acid stimulatory effect of gastrin may be explained solely by the release of histamine (Fig 1). There was no significant difference between the histamine release at the two highest gastrin concentrations (Fig 1), and in a later study ${ }^{17}$ using dextran instead of albumin as colloid, ${ }^{18}$ both acid secretion and histamine release reached maximum at a gastrin concentration of $520 \mathrm{pmol} / \mathrm{l}$. In these studies we used the phosphodiesterase inhibitor isobutyl methylxanthine (IBMX) to augment the acid secretion. IBMX, however, does not affect histamine release. ${ }^{19} \mathrm{We}$ have also shown that both somatostatin ${ }^{20}$ and the prostaglandin $E_{1}$ analogue misoprostol ${ }^{21}$ inhibit gastrin induced histamine release and acid secretion as well as histamine stimulated acid secretion. Moreover, gastrin stimulated acid secretion and histamine release are heavily dependent on the extracellular calcium concentration, in contrast to histamine stimulated acid secretion which is unaffected..$^{18}$ Stimulation of the vagal nerves resulted in a release of histamine in insufficient amounts to explain completely the stimulation of acid secretion. ${ }^{19}$ The muscarinic-1 agonist $\mathrm{McN}-\mathrm{A}-343$ stimulates acid secretion without affecting histamine release, thus suggesting that the muscarinic receptor on the parietal cell, but not on the histamine producing cell, is of the M-1 type. ${ }^{19}$ Curiously, gastrin releasing peptide slightly stimulates acid secretion while concomitantly inhibiting histamine release. ${ }^{22}$ This effect is attenuated by somatostatin antiserum, suggesting that somatostatin release could explain the inhibitory effect of gastrin releasing peptide on histamine release. ${ }^{22}$ Using different histamine receptor agonists and antagonists, we were also able to show that histamine release is inhibited by a modified $\mathrm{H}_{2}$ receptor. ${ }^{23}$

The regulation of acid secretion in the rat is illustrated in Figure 2. According to our results, therefore, it is not necessary to postulate the presence of a gastrin receptor on the rat parietal cell to explain the stimulation of acid secretion by gastrin. The specific trophic effect of gastrin on the histamine producing enterochromaffin like cells also makes it highly likely that these have a gastrin receptor. ${ }^{24}$ It should be stressed that there generally seems to be a close relation between the stimulation of function and growth. ${ }^{25-27}$ The moderate general tropic effect of gastrin on the oxyntic mucosa may be mediated by substances released from the enterochromaffin like cell such as the postulated gastrocalcin ${ }^{28}$ or histamine itself. ${ }^{29}$

\section{Species differences?}

In the rat, there is obviously no need for a gastrin receptor on cells other than the enterochromaffin like cells to explain the gastrin induced stimulation of acid secretion and mucosal growth. The rat has been claimed to be an odd species with regard to the regulation of gastric acid secretion. ${ }^{30}$ In that species histamine has been reported to be a poor gastric acid secretagogue..$^{30}$ It is true that in conscious rats histamine seems to produce a lower maximal acid secretion than gastrin. ${ }^{31}{ }^{32}$ In the totally isolated vascularly perfused rat stomach, however, histamine is appreciably more efficient than gastrin. ${ }^{16}$ This 


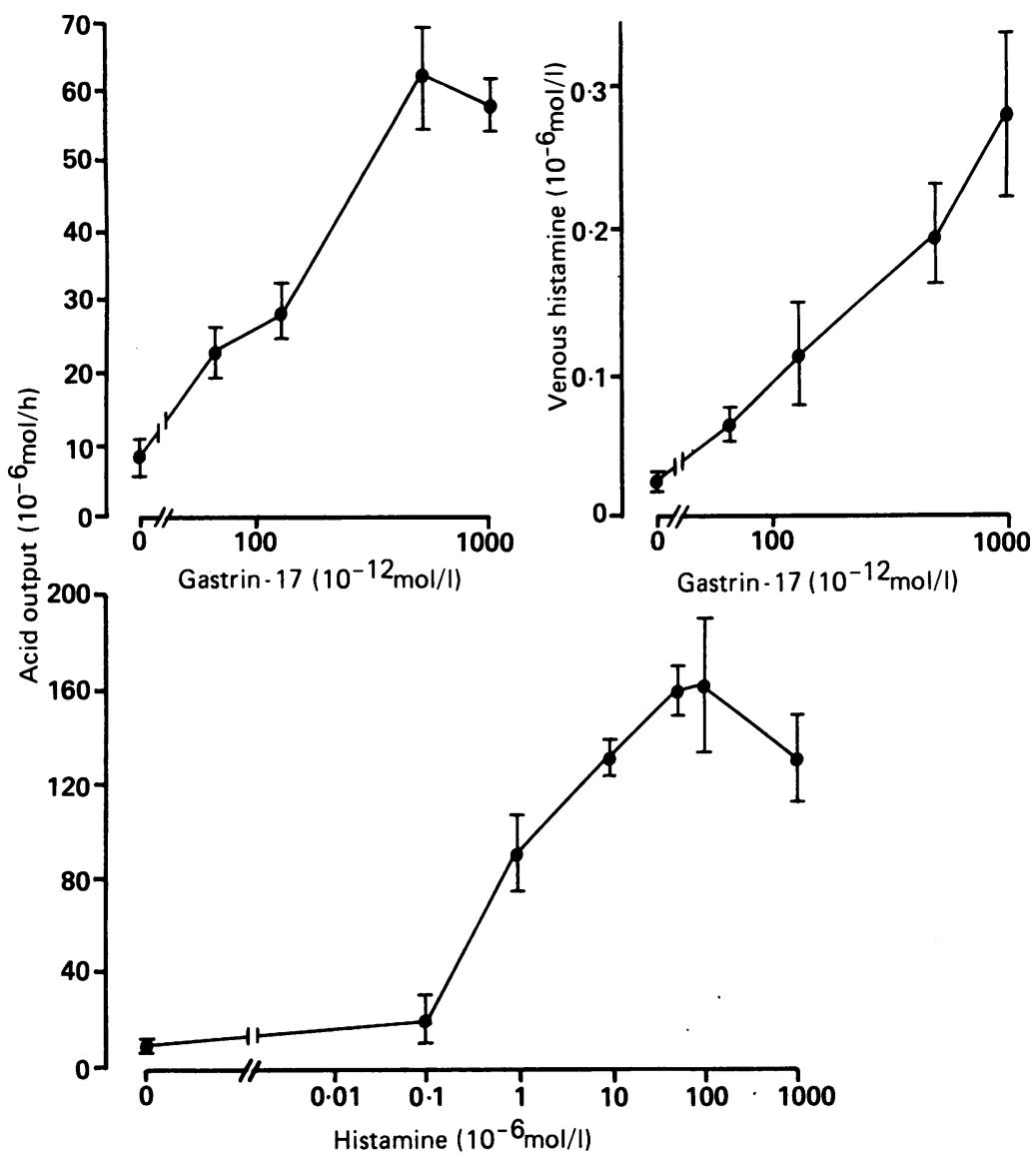

Figure 1: The effect of gastrin on acid secretion and histamine release into the venous drainage of the isolated vascularly perfused rat stomach compared with the effect of histamine on acid secretion in the same model. (Figure taken from results from references 14 and 15.)

discrepancy in results between conscious rats and vascularly perfused isolated rat stomachs may be explained by the extragastric toxic effects of high concentrations of histamine. In fact, in conscious rats the selective $\mathrm{H}_{2}$ receptor agonist, dimaprit, was found to produce a higher maximal acid secretion than histamine and, in contrast to histamine, did not cause a reduction in acid secretion with higher doses. ${ }^{32}$ In the rat, however, the parietal cell sensitivity for histamine is low, ${ }^{1633}$ explaining why histamine cannot be administered in vivo to that animal in doses that would produce maximal acid secretion. The low potency of histamine in the rat is compensated for by the high histamine forming capacity in that species.' Kahlson et al convincingly showed that there is a close inverse interspecies relation between the histamine forming capacity and the sensitivity towards histamine. 9 This histamine forming capacity does not correlate with the total oxyntic mucosal histamine content. ${ }^{934}$ On the other hand, the histamine forming capacity of the oxyntic mucosa in a species is closely correlated with the density of the enterochromaffin like cells but not the mast cells. ${ }^{95}$ In spite of this, the mast cell has been regarded as the source of the histamine that takes part in the regulation of acid secretion. ${ }^{36}$ No physiological stimulus, however, has been shown to influence the histamine release from the mast cells. ${ }^{37}$

Furthermore, histamine has now been found in enterochromaffin like cells in most species, including dog and man. ${ }^{35}$ As in the rat, gastrin releases histamine from the canine stomach, ${ }^{38}$ as well as from carcinoid tumours in man. ${ }^{39}$ Pentagastrin has also been reported to induce a release of histamine into the gastric lumen and the blood in duodenal ulcer patients. ${ }^{40} \mathrm{~A}$ specific trophic effect of gastrin on the enterochromaffin like cell is also found in man. ${ }^{4142}$ Therefore, there is no doubt that the enterochromaffin like cells in many species produce histamine and that these cells have gastrin receptors.

As already stated, there is within each species an inverse relation between the histamine forming capacity of the oxyntic mucosa and the histamine acid secretagogue potency. ${ }^{9}$ Before considering the role of histamine in the stimulation of acid secretion, therefore, one has to know the histamine potency in that particular species. On isolated parietal cells and isolated glands from rodent oxyntic mucosa, gastrin alone has been reported to have $\mathrm{no}^{3343}$ or only a faint $^{44}$ effect on acid secretion as evaluated by aminopyrine uptake. It should be remembered that histamine has a low potency in these species." In the dog on the other hand, where histamine is a rather potent secretagogue, ${ }^{945}$ gastrin was found to have a weak stimulatory effect on the aminopyrine uptake of the enriched parietal cell fraction. ${ }^{45}$ Cimetidine did not inhibit this slight increase in aminopyrine uptake. ${ }^{45}$ The author commented, however, because of the small response to gastrin and the relatively wide standard errors, small inhibitory effects by cimetidine could have been missed. ${ }^{45}$ Moreover, even in this relatively pure parietal cell fraction, cimetidine inhibited the stimulatory effect of IBMX suggesting residual histamine in the medium. ${ }^{45}$ It should also be remembered that

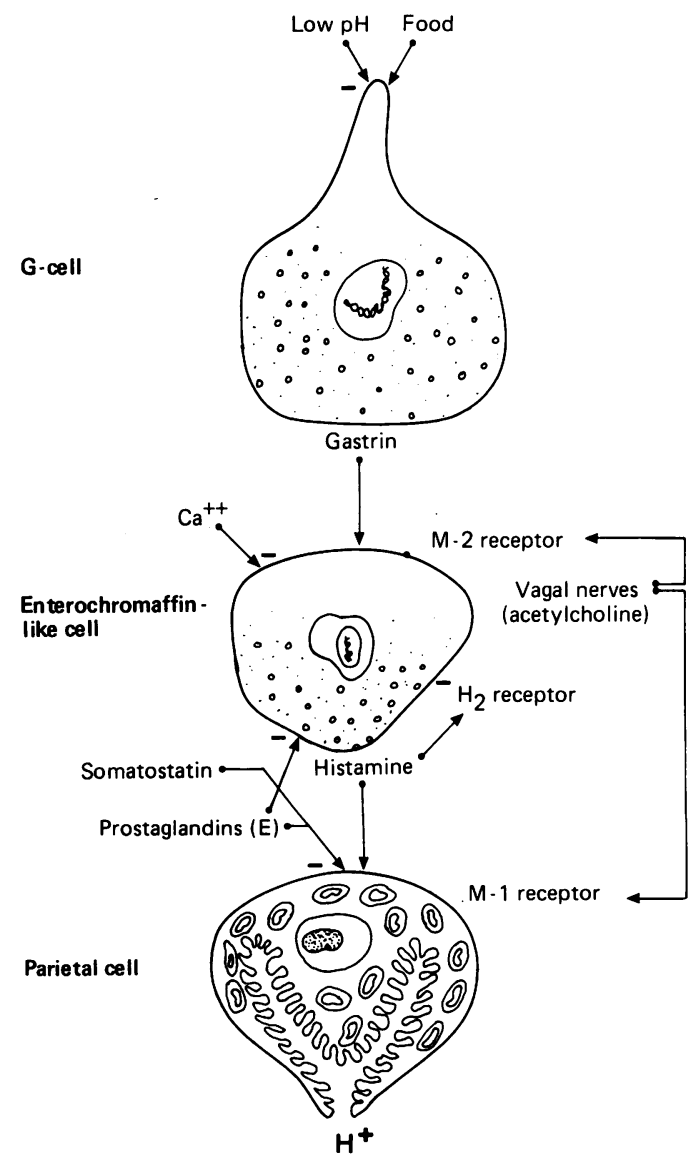

Figure 2: Regulation of acid secretion in the rat. 
Rouff $e t a l^{46}$ have shown that histamine producing small cells followed the parietal cells during gradient centrifugation. Therefore, since the parietal cell fraction of Soll ${ }^{45}$ was not completely pure, and histamine was probably present in the medium, it is possible that the slight stimulatory effect of gastrin was the result of histamine diffusing from histamine producing cells (presumably enterochromaffin like cells) into the medium. It should be stated that some parietal cells in close proximity to the enterochromaffin like cells could be exposed to higher concentrations of histamine than that found in the total medium. Such an explanation could also be used for the stimulation by gastrin of the aminopyrine uptake in pig parietal cells. ${ }^{478}$ Gastrin also releases somatostatin from $D$ cells present in the oxyntic mucosa, ${ }^{49}$ and the low efficacy of gastrin as a stimulator of aminopyrine uptake in isolated gastric glands and parietal cells could possibly be explained by the concomitant release of stomatostatin from $D$ cells present in the preparation. However, pentagastrin releases somatostatin from the stomach in vivo, mainly via the stimulation of acid secretion. ${ }^{490}$ Nevertheless, there seems to be a slight direct stimulatory effect of (penta) gastrin on the somatostatin release from the $\mathrm{D}$ cell. $^{\mathrm{s1}}$ Therefore, it is possible, but not likely, that the discrepancy in efficiency between isolated glands or parietal cells on one hand and the intact animal or isolated stomach on the other could be caused by a disproportionate somatostatin release.

The stimulation of acid secretion in vivo by gastrin may be completely inhibited by $\mathrm{H}_{2}$ blockers, ${ }^{5253}$ whereas variable results have been reported in isolated glands and cells. ${ }^{4554}$ The discrepancy between these results is difficult to explain. However, the phosphodiesterase inhibitor IBMX in vitro augments the acid secretory response to gastrin ${ }^{44} 47$ although gastrin is thought not to have cyclic adenosine monophosphate as its second messenger. ${ }^{54}$ Even in man, the acid stimulatory effect of gastrin in vivo is competitively inhibited by $\mathrm{a}_{2}$ blocker up to a certain gastrin concentration. ${ }^{55}$ This could be explained by a maximal gastrin stimulated histamine release, in keeping with the finding in the totally isolated vascularly perfused rat stomach that maximal histamine release and maximal acid secretion occur at the same concentration of gastrin. 1517 Furthermore, the pentagastrin stimulation of acid secretion in isolated canine oxyntic mucosa was, in contrast to the histamine stimulation, reported to be short lived and could be inhibited by an $\mathrm{H}_{2}$ blocker. ${ }^{56}$ Therefore, even in the dog, gastrin stimulation of acid secretion may be explained by histamine release. Moreover, the enterochromaffin like cells have a very intimate position with the parietal cells in most species including $\operatorname{dog}^{57}$ and man. ${ }^{58}$

The binding of ${ }^{125}$ I gastrin has been used to detect the gastrin receptor both in mucosal cell homogenates, ${ }^{5960}$ and on cells. ${ }^{61}$ The binding to mucosal homogenates does not tell anything about the cell type responsible for the binding. Moreover, the gastrin receptor assay ${ }^{59}$ is at best difficult to reproduce. ${ }^{60}$ The binding of ${ }^{125}$ gastrin to the dog parietal cell fraction ${ }^{6}$. .epresents the best indication for the presence of a gastrin receptor on a cell type other than the enterochromaffin like cell. Since no studies report specific staining procedures for these cells in the examined parietal cell fraction the occurrence of enterochromaffin like cells in the parietal cell fraction can not be excluded. ${ }^{46}$

In conclusion, there is no doubt that the enterochromaffin like cells in most species produce histamine and that these cells have a gastrin receptor. In the rat, it is not necessary to postulate that there is a gastrin receptor on any other cell type. Even in other species, the effects of gastrin on acid secretion and oxyntic mucosal growth may be mediated by histamine and possibly other substances released from the enterochromaffin like cells.

1 Pavlov IP. The work of the digestive glands. 2nd ed. London: Griffin, 1910.

2 Edkins JS. On the chemical mechanism of gastric secretion. Proc Soc Med [B] 1905; 76: 376

3 Popielski L. $\beta$-Imidazolyläthylamin und die Organextrakte. I. $\beta$-Imidazolyläthylamin als mächtiger Erreger der Magendrüsen. Pflügers Arch 1920; 178: 214-36.

4 Blair EL, Greenwell JR, Grunk ER. Gastrin response to meals of different composition in normal subjects. Gut 1975; 16: 766-73.

5 Walsh JH, Richardson CT, Fordtran JS. pH dependence of acid secretion and gastrin release in normal and ulcer subjects. F Clin Invest 1975; 55: 462-8.

6 Debas HT, Hollinshead J, Seal A, Soon-Shiong P, Walsh JH. Vagal control of gastrin release in the dog: pathways for stimulation and inhibition. Surgery 1984; 95: 34-7.

7 Varner A, Modlin I, Walsh J. High potency of bombesin for stimulation of human gastrin release and gastric acid secretion. Reg Peptides 1981; 1: 289-96.

8 Bloom SR, Mortimer CH, Thorner MO, et al. Inhibition of gastrin and gastric-acid secretion by growth hormone releasegastrin and gastric-acid secretion by growth hor

9 Kahlson G, Rosengren E, Svahn D, Thundberg R. Mobilization and formation of histamine in the gastric mucosa as related to acid secretion. F Physiol (Lond) 1964; 174: 400-16.

10 MacIntosh FC. Histamine as a normal stimulant of gastric secretion. Qf Exp Physiol 1938; 28: 87-98.

11 Code CF. Histamine and gastric secretion. In: Wolstenholme GEW, O'Connor CM, eds. Ciba Foundation symposium on histamine. London: J \& A Churchill, 1956: 189-219.

12 Ekblad EBM. Histamine and CAMP as possible mediators of acetylcholine-induced acid secretion. Am $\mathcal{F}$ Physiol 1980; 239: G255-60.

13 Black JW, Shankley NP. How does gastrin act to stimulate oxyntic cell secretion? Trends Pharmacol Sci 1987; 8: 486-90.

14 Kleveland PM, Waldum HL, Bjerve KS, Fjøsne HE. Bioassay of gastrin, using the totally isolated, vascularly perfused rat stomach. Scand f Gastroenterol 1986; 21: 945-50.

15 Sandvik AK, Waldum HL, Kleveland PM, Schulze Søgnen B. Gastrin produces an immediate and dose-dependent histamine release preceding acid secretion in the totally isolated, vascularly perfused rat stomach. Scand $\mathcal{F}$ Gastroenterol 1987; 22: 803-8.

16 Kleveland PM, Waldum HL, Larsson H. Gastric acid secretion in the totally isolated, vascularly perfused rat stomach. A selective muscarinic- 1 agent does, whereas gastric does not, augment maximal histamine-stimulated acid secretion. Scand f Gastroenterol 1987; 22: 705-13.

17 Sandvik AK, Waldum HL. Rat gastric histamine release: a sensitive gastrin bioassay. Life Sci 1990; 46: 453-9.

18 Sandvik AK, Kofstad J, Holst JJ, Waldum HL. Ionized calcium influences gastrin stimulated histamine release and acid secretion, but not histamine stimulated acid output in the totally isolated vascularly perfused rat stomach. Acta Physiol Scand 1988; 134: 443-8.

19 Sandvik AK, Kleveland PM, Waldum HL. Muscarinic M2 stimulation releases histamine in the totally isolated, vascularly perfused rat stomach. Scand f Gastroenterol 1988; 23: 1049-56.

20 Sandvik AK, Waldum HL. The effect of somatostatin on baseline and stimulated acid secretion and vascular histamine release from the totally isolated vascularly perfused rat release from the totally isolated vascu

21 Sandvik AK, Waldum HL. The effect of misoprostol on baseline and stimulated acid secretion and on gastrin and histamine release in the totally isolated, vascularly perfused histamine release in the totally isolated, vascularly per

22 Sandvik AK, Holst JJ, Waldum HL. The effect of gastrinreleasing peptide on acid secretion and the release of gastrin, somatostatin, and histamine in the totally isolated, vascularly perfused rat stomach Scand F Gastroenterol 1989; 24: 9-15.

23 Sandvik AK, Lewin MJM, Waldum HL. Histamine release in the isolated vascularly perfused stomach of the rat: regulation by autoreceptors. BrF Pharmacol 1989; 96: 557-62.

24 Creutzfeldt W, Stöckmann F, Conlon JM, Fölsch UR, Bonatz $G$, Wülfrath $M$. Effect of short- and long-term feeding of 
omeprazole on rat gastric endocrine cells. Digestion 1986; 35 (suppl 1): 84-97.

25 Axelson J, Ekelund M, Håkanson R, Sundler F. Gastrin and the vagus interact in the trophic control of the rat oxyntic mucosa. Reg Peptides 1988; 22: 237-43.

26 Johnson LR. Effects of gastrointestinal hormones on pancreatic growth. Cancer 1981; 47: 1640-5.

27 Petersen H, Solomon T, Grossman MI. Effects of chronic pentagastrin, cholecystokinin, and secretin on pancreas of pentagastrin, cholecystokinin, and sec
rats. Am f Physiol 1978; 234; E286-93.

28 Håkanson R, Axelson J, Persson P, Sundler F. Which effects of antral gastrin are physiological? In: Bali J-P, Martinez J, eds. Gastrin and cholecystokinin. Chemistry, physiology and pharmacology. Amsterdam: Elsevier Science Publishers, 1987 ; 163-79.

29 Waldum HL, Sandvik AK. Histamine and the stomach. Scand f Gastroenterol 1989; 24: 130-9.

30 Johnson LR. Control of gastric secretion: no room for histamine? Gastroenterology 1971; 61: 106-18.

31 Adeshek K, Grossman MI. Response of rats with gastric fistulas to injections of gastrin. Proc Soc Exper Biol Med 1963; 112: 629.

32 Petersen $\mathrm{H}$, Grossman MI. Stimulation of gastric acid secretion by dimaprit in unanesthetized rats. Agents Actions 1978; 8: 566-7.

33 Dial E, Thompson WJ, Rosenfeld GC. Isolated parietal cells: Histamine response and pharmacology. 7 Pharmacol Exp Ther 1981; 219: 585-90.

34 Lorenz W, Thon K, Barth H, Neugebauer E, Reimann H-J, Kusche J. Metabolism and function of gastric histamine in health and disease. 7 Clin Gastroenterol 1983; 5 (suppl 1): 3756.

35 Håkanson R, Sundler F. Localisation of gastric histamine: Immunocytochemical observations. Med Biol 1987; 65: 1-7.

36 Soll AH, Berglindh T. Physiology of isolated gastric glands and parietal cells: receptors and effectors regulating function. In: Johnson LR, ed. Physiology of the gastrointestinal
2nd edition, New York: Raven Press, 1987: 883-909.

37 Soll AH, Toomey M, Culp D, Shanahan F, Beaven MA. Modulation of histamine release from canine fundic mucosal mast cells. Am $\mathcal{F}$ Physiol 1988; 254: G40-8.

$38 \mathrm{Gerber} \mathrm{JG,} \mathrm{Barnes} \mathrm{JS.} \mathrm{Histamine} \mathrm{release} \mathrm{in} \mathrm{vivo} \mathrm{by} \mathrm{pentagastrin}$ from the canine stomach. $\mathcal{F}$ Pharmacol Exp Ther 1987; 243 887-92.

39 Roberts LJ, Bloomgarden ZT, Marney SR, Rabin D, Oates JA. Histamine release from a gastric carcinoid: provocation by pentagastrin and inhibition by somatostatin. Gastroenterology 1983; 84: 272-5.

40 Man WK, Ingoldby CJH, Spencer J. Is pentagastrinstimulated secretion mediated by histamine? Gut 1984; 25 : 965-70.

41 Bordi C, Cocconi G, Togni R, Vezzadini P, Missale G. Gastric endocrine cell proliferation. Association with ZollingerEllison syndrome. Arch Pathol 1974; 98: 274-8.

42 Bordi C, Pilato F, Carfagna G, et al. Argyrophil cell hyperplasia of fundic mucosa in patients with chronic atrophic gastritis. Digestion 1986; 35 (suppl 1): 130-43.

43 Berglindh T, Helander HF, Öbrink KJ. Effects of secretagogues on oxygen consumption, aminopyrine accumulation and morphology in isolated gastric glands. Acta Physiol Scand 1976; 97: 401-14.

44 Chew CS, Hersey SJ. Gastrin stimulation of isolated gastric glands. Am F Physiol 1982; 242: G504-12.

45 Soll AH. Secretagogue stimulation of $\left[{ }^{14} \mathrm{C}\right]$ aminopyrine accumulation by isolated canine parietal cells. Am $\mathcal{F}$ Physiol 1980; 238: G366-75.

46 Ruoff H-J, Reutter K, Schepp W. Histamine content and release of isolated rat gastric mucosal cells. Agents Actions 1985; 16: $202-4$.

47 Norberg L, Ljungström M, Vega FV, Mårdh S. Stimulation of acid formation by histamine, carbachol and pentagastrin in isolated pig parietal cells. Acta Physiol Scand 1986; 126: 38590

48 Mårdh S, Song Y-H, Carlsson C, Björkman T. Mechanisms of stimulation of acid production in parietal cells isolated from the pig gastric mucosa. Acta Physiol Scan 1987; 131: 589-98.

49 Schubert ML, Edwards NF, Arimura A, Makhlouf GM Paracrine regulation of gastric acid secretion by fundic somatostatin. Am $f$ Physiol 1987; 252: G485-90.

50 Schubert ML, Edwards NF, Makhlouf GM. Regulation of gastric somatostatin (SS) secretion by luminal acid: a feedback control mechanism. Gastroenterology 1986; 90: 1621 .

51 Soll AH, Yamada T, Park J, Thomas LP. Release of somatostatinlike immunoreactivity from canine fundic mucosal cells in primary culture. Am f Physiol 1984; 247: G558-66.

52 Grossman MI, Konturek SJ. Inhibition of acid secretion in the dog by metiamide, a histamine antagonist acting on $\mathrm{H}-2$ receptors. Gastroenterology 1974; 66: 517-21.

53 Aadland E, Berstad A, Semb LS. Inhibition of pentagastrinstimulated gastric secretion by cimetidine in healthy subjects. In: Burland WL, Simkins MA, eds. Cimetidine. Amsterdam-Oxford: Excerpta Medica, 1977: 87-97.

54 Berglindh T. Gastric secretion and the use of cellular and subcellular systems in gastric research. Front Gastrointest subcellular systems in

55 Leth R, Olbe L, Haglund U. The pentagastrin-induced gastric acid response in humans. Scand $\mathcal{F}$ Gastroenterol 1988; 23: 224-8

56 Rangachari PK, McWade D. An "epithelial" preparation from the canine gastric mucosa: responses to secretagogues. Am $\mathcal{F}$ Physiol 1989; 257: G46-51.

57 Hui W-M, Liu H-C, Lam S-K, Koo A. Histamine containing cells in gastric fundus of dogs. Cell Mol Biol 1987; 33: 74754.

58 Rubin W. An unusual intimate relationship between endocrine cells and other types of epithelial cells in the human stomach. $₹$ Cell Biol 1972; 52: 219-27.

59 Takeuchi K, Speir GR, Johnson LR. Mucosal gastrin receptor. I. Assay standardization and fulfillment of receptor criteria. I. Assay standardization and fulfillm
Am F P hysiol 1979; 237: E284-94.

60 Kleveland PM, Waldum HL. Binding and degradation of ${ }^{125} \mathrm{I}-$ gastrin by plasma membranes from homogenized rat gastric mucosa. Scand F Gastroenterol 1986; 21: 547-55.

61 Soll AH, Amirian DA, Thomas LP, Reedy TJ, Elashoff JD. Gastrin receptors on isolated canine parietal cells. $\mathcal{F}$ Clin Invest 1984; 73: 1434-47. 